\title{
Implications of the Bakassi conflict resolution for Cameroon
}

\author{
Francis Menjo Baye ${ }^{\star}$
}

\begin{abstract}
This paper sketches a conceptual framework of international conflict dynamics and resolution, examines the geopolitics of the Bakassi dispute between Nigeria and Cameroon, and outlines socio-economic implications of its peaceful settlement. Neglect and subsequent discovery of oil deposits subjected the Bakassi Peninsula to claims and counter-claims for sovereignty, military occupation and recourse to the International Court of Justice (ICJ). The ICJ's ruling in 2002 in favour of Cameroon, although based on sound historical evidence, faced implementation difficulties. However, following mediation by the United Nations (UN) Secretary-General, good faith by protagonists, the Green-tree Agreement and subsequent instruments, Nigeria completed the withdrawal of its military, police and administration from the Bakassi Peninsula by 14 August 2008. Putting aside disruptive activities by social movements, the entire process could be viewed as a model in peaceful resolution of border conflicts. Implications of the settlement anchor on expenditure-reducing and expenditure-switching effects, wealth-generating effects, and enhanced
\end{abstract}

\footnotetext{
* Dr Francis Baye is Associate Professor in the Department of Economics and Management, University of Yaoundé II, Yaoundé, Cameroon.
} 


\section{Francis Menjo Baye}

cross-border activities. Infrastructural developments and effective presence are considered essential elements in border management policies.

\section{Introduction}

Territorial claims, ideology, colonialism, nationalism, religion and natural resources have typically been the main sources of conflict throughout the world. While the influence of some of these is waning, struggles for the control of valuable natural resources have remained a persistent feature of national and international affairs for decades. In addition to helping some of the most corrupt and oppressive regimes to remain in power, natural resources have been fuelling conflicts within and between African countries. Such conflict situations typically take the form of territorial disputes over the possession of oil-laden border areas, factional struggles among the leaders of oil-rich countries, and major inter-state wars over the control of vital oil and mineral zones (Klare 2004).

Africa was largely controlled by indigenous people in the 1870 s, but by $1914^{1}$ it became almost exclusively subjugated and divided into protectorates/colonies by the European powers (Rourke 1997; Aghemelo and Ibhasebhor 2006). The colonial boundaries in these configurations were not established according to the various indigenous groupings. Grouping nations together in some cases and dividing them in others was a common feature as long as it was consistent with the security and economic interests of the colonial powers. After independence, most of Africa became and is still troubled by the legacy of trying to get originally different indigenous groupings to live peacefully in a single country or to get the same ethnic group to live peacefully in different neighbouring countries. As in most of Africa, therefore, the origins of the conflict situation between Cameroon and Nigeria over border issues can be traced to the colonial era and some postindependence political activities.

The border between Cameroon and Nigeria extending from Lake Chad to the Gulf of Guinea has been a bone of contention between the two territories dating back to 1913. However, the knowledge that the Bakassi Peninsula harbours

1 Thirty years after the Berlin Conference. 


\section{Implications of the Bakassi conflict resolution for Cameroon}

important deposits of oil/gas reserves triggered mounting hostilities and military confrontations in the early 1990s between Cameroon and Nigeria. According to Klare (2004), the close connection between oil and conflict derives from three essential features of petroleum: (1) its vital importance to the economic and military power of nations; (2) its irregular geographical distribution; and (3) its imminent changing centre of gravity.

In 1993 Nigerian troops occupied the Bakassi Peninsula. In 1994, after serious incidents of border incursions that provoked shooting, and after many casualties and deaths of soldiers had been recorded on both sides, Cameroon submitted its entire set of border-related disputes with Nigeria to the International Court of Justice at The Hague for adjudication. After examining the case for eight years, the World Court ruled that Cameroon is the rightful owner of the oil-rich Peninsula, basing its argument on the 1913 Anglo-German Treaty which traced the borders between the two colonial powers.

Following intensive diplomatic activities culminating in the 12 June 2006 Greentree Agreement ${ }^{2}$ brokered by the United Nations and witnessed/guaranteed by four world powers - Britain, France, Germany and the United States - Nigeria eventually agreed to unconditionally hand over the oil-rich Peninsula to Cameroon. On 14 August 2006 Nigeria effectively pulled out its military and the Cameroonian flag was hoisted. Two years later (14 August 2008) the remaining Nigerian administration and police left the Peninsula. In this context, two key questions arise: is the outcome of the Bakassi conflict a model of conflict resolution and economic cross-border development, or is it more a situation of conflict dynamics, crisis and economic instability?

The main objective of this paper is to evaluate the implications of the Bakassi conflict settlement between Cameroon and Nigeria for sustainable peace and economic development. The specific objectives are: (1) to develop a conceptual framework of international conflict dynamics and resolution; (2) to examine the geopolitics of the Bakassi question; (3) to discuss implications of the verdict of

2 'The Green-tree Agreement' is the official appellation of the agreement between the Republic of Cameroon and the Federal Republic of Nigeria concerning the modalities of withdrawal and transfer of authority in the Bakassi Peninsula. 


\section{Francis Menjo Baye}

the International Court of Justice and subsequent instruments for international conflict resolution and socio-economic development in Cameroon; and (4) to outline policy recommendations on the basis of the analysis. According to these objectives, the rest of the paper is organised in four sections.

\section{International conflict dynamics and resolution: $A$ conceptual framework}

In this section, the nature of international conflicts, their dynamics, and oil as engine and fuel for conflict situations are discussed. The dispute settlement linkages between Cameroon and Nigeria are then established.

\subsection{Nature of international conflicts}

Conflict is as old as the history of mankind and therefore normal, natural and unavoidable, yet it can generate negative and very destructive impacts, as well as awareness, economic growth and development (Ivorgba 2005). What matters is our response to conflict and post-conflict situations. Conflict is an indication that somehow, there is misunderstanding that requires attention and proper action.

International conflicts might occur between governments striving to monopolise the exploitation of resources in disputed territories. It could arise when a nation-state intervenes in the domestic disputes of another state. Occasionally, a conflict may ensue where the nationals of one state are attacked, dehumanised, killed or maimed by the agents of another state. Conflicts between countries are often presented as occurring between their governments and such situations are either conducted or perceived as inter-governmental struggles, while the bone of contention is usually territory or some other economic resource (Asobie 2003). It is seldom the welfare of the ordinary citizens of the states concerned that provokes conflict situations in Africa. Even when such reasons are brandished, they often turn out to be attempts at concealing other agendas.

As noted by Asobie (2003), a deeper examination may reveal that, in essence, international conflicts are struggles between primary social classes, clashing across national boundaries. In this regard, the real actors in international conflicts 


\section{Implications of the Bakassi conflict resolution for Cameroon}

are social classes (for instance, the ruling elite) which, in their struggles, mobilise and use the various state institutions to push forward their goals. For the most part, contests are related to the control of productive resources. Even when such resources are exploited, the proceeds are typically distributed disproportionately in favour of the ruling classes and their cronies/protégés. As the working class citizens become aware of this unequal sharing, the more vulnerable ones may be attracted into social movements conceived and sponsored by disgruntled dropouts from the ruling class. Such social movements are fashioned to operate in opposition to the ruling elite using all sorts of means, while expecting better days ahead.

Hiding behind governments, in some international conflicts, are the monopolistic capitalists operating trans-nationally with multinational tentacles. Major oil and mineral exploiting companies belong to this category. These dominant expatriate capitalists are typically in simultaneous alliances with the respective ruling classes in the exploitation of resources in both countries. These unpleasant alliances often manifest in millions of hard currency diverted and stacked away in foreign banks, and open avenues for interventions in domestic affairs of host countries that serve the interest of multinationals even at the cost of inter-state conflicts. Yet victims of such conflicts remain the working people - especially the youth, women and child soldiers, as well as old people who find it difficult to escape conflict zones, emigrate or seek refugee status elsewhere.

\subsection{Dynamics of international conflicts}

The dynamics of most international conflicts may be shaped by three critical factors:

(1) The nature and size of the booty that would accrue from the conflict. This refers to the relative utility and size of the presumed productive resources that the victor might gain after the struggle.

(2) The nature of the relationship between the social classes that constitute the primary actors in conflict. Once monopolistic capitalists either on one side or on 


\section{Francis Menjo Baye}

both sides of the state territorial boundaries have high stakes in the outcome of the conflict, the spiral of international conflicts will be almost unending. ${ }^{3}$

(3) The nature of domestic politics in the nation-states that form the bases for the contending parties. This includes the nature of the regime in power. Authoritarian/dictatorial regimes have the tendency to provoke the emergence of violent inter-state politics, so as to divert attention from burning domestic issues and prolong their stay in power.

Generally, when violent conflicts erupt between two contending ruling classes of two distinct countries, they are extensions of violent intra-state conflicts promoted by the various discontented social groups who may be having international connections. Hoffmann (1985) observed that one definitely cannot imagine a non-violent diplomacy as long as violence has not been eliminated from intra-state politics. In this connection, social movements within territorial boundaries frequently seek to establish links with similar bodies in neighbouring countries and will spare no effort in taking advantage of a conflict situation to canvass for international recognition.

\subsection{Oil as engine and fuel for conflict situations}

It is possible that in some cases conflicts originated before the discovery of petroleum, but became interwoven with oil issues as the importance of oil as a factor of production increased. The drivers of such tendencies are territorial disputes, separatist struggles and factional/dynastic struggles.

Territorial disputes occur in border zones and offshore areas that were thought to possess no particular value, but suddenly become very valuable with the discovery of oil. For several decades, neither the Nigerian nor Cameroonian ruling elite showed any particular interest in the Bakassi Peninsula. Neither showed any concern nor initiated any programme that was capable of ameliorating the deplorable conditions of mass poverty, squalor and destitution in which most Bakassi residents live. But struggles over the ownership of Bakassi

3 In some cases, the monopolistic capitalists do not need to wait for the end of the conflict to have their benefits. They prey on the on-going conflict through the sale of arms (sometimes to both conflicting parties) and the exploitation of the resources under contention for a pittance. 


\section{Implications of the Bakassi conflict resolution for Cameroon}

by Nigeria and Cameroon began immediately it was discovered in the eighties that the Peninsula was floating on reserves of crude oil (Sango 2002). It was only then that the elite of both countries started making serious claims and counterclaims over the territory. ${ }^{4}$

Separatist struggles occur when oil is produced or presumed to exist in an area largely inhabited by an ethnic minority and the bulk of oil revenues go or are expected to go to government officials in the national capital. In this context, members of the ethnic minority often perceive a strong incentive to break away and establish their own ethnic state, with a view to getting all of the oil revenue. This sort of struggle is occurring in the southern part of Sudan, where the predominantly Christian population is struggling for independence and in Cameroon, where the Southern Cameroon National Council (SCNC) sympathises with advocates for the independence of the Bakassi Peninsula as 'The Republic of Ambazonia' (Gumne 2006). In some cases such as the Delta region of Nigeria, ethnic minorities are fighting to gain greater autonomy (and a larger share of oil revenues) rather than a separate state.

Factional/dynastic struggles occur because whoever controls the government of oil-producing states also controls the allocation of oil revenues. Those in control will seek to retain power for as long as possible, using heavy-handed repression and election rigging, while those excluded from power will have a powerful incentive to use any means necessary to gain control (including armed rebellion, terrorism, or coup d'état). These sorts of factional struggles have been a consistent pattern in countries like Nigeria and Saudi Arabia, as well as in most oil-rich states. In other countries, especially Venezuela, disputes over the allocation of oil revenues have taken the form of political violence between competing parties and interest groups (Klare 2004).

4 In essence, the struggle by the Nigerian and Cameroonian ruling classes for ownership of the Peninsula is not dictated by concern for the well-being of the residents of Bakassi, but rather for the rich oil reserves and fishing grounds found in the area and its strategic location in the Gulf of Guinea. Indeed, Nigeria started undertaking some social infrastructural developments in Bakassi only in 1997, four years after it occupied the Peninsula. 


\section{Francis Menjo Baye}

\subsection{Dispute settlement linkages between Cameroon and Nigeria}

The conflict between Nigeria and Cameroon was a boundary and territorial dispute - the Bakassi Peninsula being the most contested. Attempts were made in the past to resolve the dispute through bilateral negotiations, but in 1981, and again in 1993, 1994 and 1996, the dispute nearly escalated to a war. Between 1994 and 2002, the matter was before the International Court of Justice at The Hague. A judgment was pronounced in 2002 by the ICJ on the matter and the Nigerian government issued a statement rejecting the verdict of the International Court. Yet following negotiations between the two countries, facilitated by the UN and crowned by the June 2006 Green-tree Agreement in New York and subsequent instruments, Nigeria completed the withdrawal of its military, administration and police from the Bakassi Peninsula in August 2008. This has been described as a remarkable outcome in conflict resolution in Africa. However, it will be naïve to conclude that the issue has been neatly resolved without a careful examination of the linkages propelling the conflict and resolution processes.

Figure 1 is a conflict map showing the relationships among various actors and issues in the dispute over the Bakassi Peninsula. The states in conflict are Nigeria and Cameroon, and the ICJ awarded the Peninsula to Cameroon in October 2002. After the ICJ verdict, which of course has no enforcement mechanism, the Nigerian parliament submitted that the handover would be unconstitutional and demanded a referendum (Price 2005). Even the UN body overseeing the negotiations - the Cameroon-Nigerian Mixed Commission - between the countries did indicate that technical problems delayed the transfer of the Peninsula to Cameroon. This commission was set up by the UN SecretaryGeneral on the request of President Paul Biya of Cameroon and President Olusegun Obasanjo of Nigeria and chaired by the Secretary-General's Special Representative for West Africa. Its role was to determine ways to implement the ICJ ruling and move the process forward (United Nations 2006). 
Figure 1: Conflict dynamics and settlement linkages: Cameroon, Nigeria and the Bakassi Peninsula

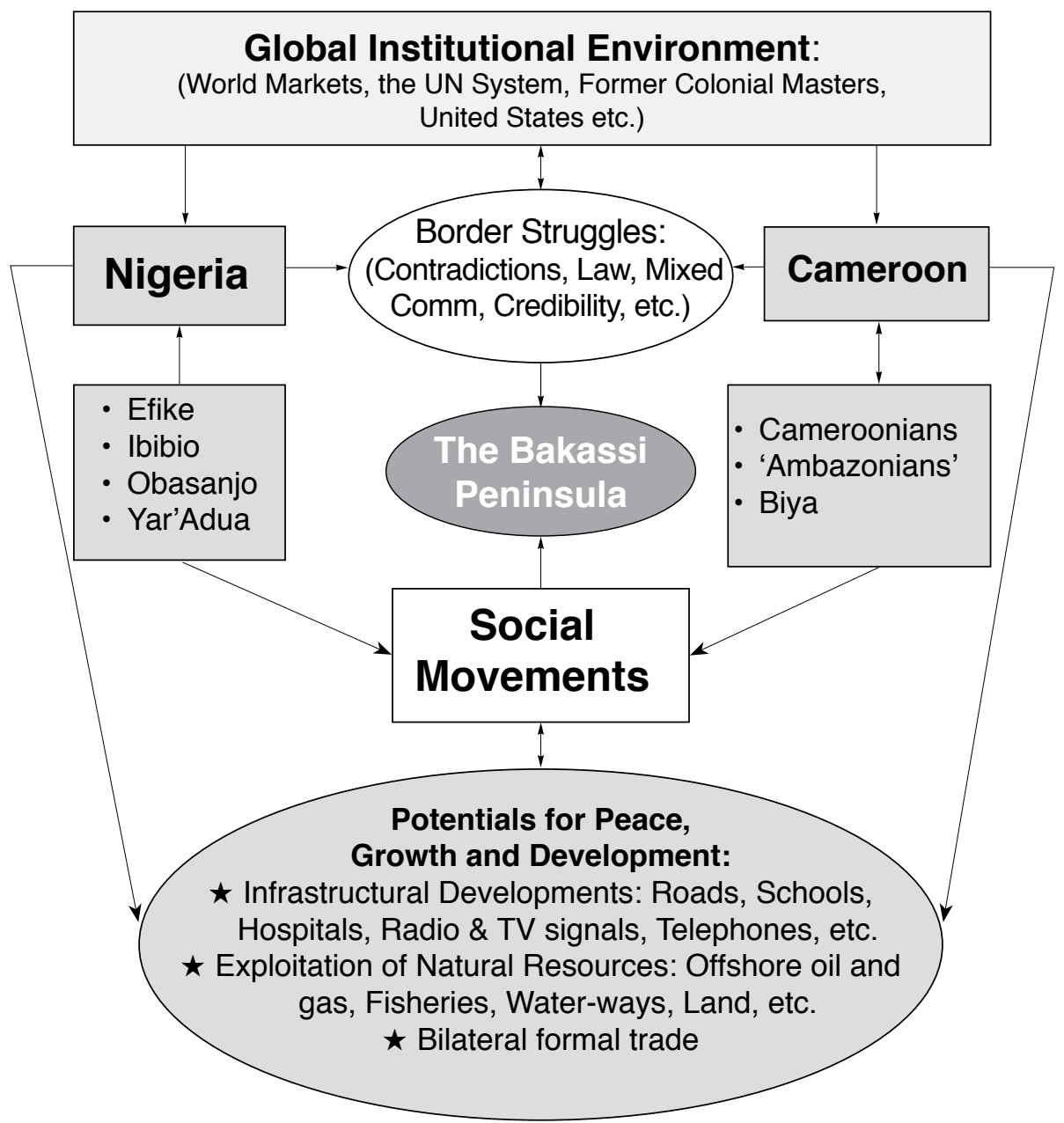

Source: Constructed by the author

Figure 1 also refers to the idea that border struggles between Cameroon and Nigeria are the product of a number of contradictions: 


\section{Francis Menjo Baye}

(1) There is a clash between tradition and modernity. In this regard, the precolonial history of the ancient kingdom of Calabar is haunting the post-colonial reality of contemporary Nigeria and Cameroon.

(2) There is the tension between cartographical fact and cultural reality. The geographical map is in conflict with the people.

(3) There is conflict between the dictates of international law and citizenship.

(4) There is a gap between the demands for raison d'être or pragmatism and the needs and concerns of citizens.

In this framework, potentials for peace and the judicious exploitation of the natural resources in and around the Bakassi Peninsula will very much depend on the 'principle of good faith' (Aghemelo and Ibhasebhor 2006) and on responses by social movements, which include the concerns of the Anglophone Cameroon secessionist movement and the Nigerian migrant community in the Bakassi Peninsula. Essentially, there are two simultaneous issues to be guarded against: (1) sabotage resulting from subsequent oil development and fisheries in the Bakassi region and (2) the potential for further violence as secessionist movements (Ambazonians), other Cameroonians, Nigerians and the inhabitants of the Bakassi Peninsula (Efike) contest or undermine the Green-tree Agreement. In this connection, accompanying measures by both Cameroon and Nigeria, as well as by the international community are needed to sustain the peace dividend.

\section{Geopolitics of the Bakassi dispute}

\subsection{The colonial legacy}

Before the scramble for Africa, Bakassi was part of the ancient kingdom of Calabar. The people in the main settlements in the Bakassi Peninsula owed allegiance to the Obong of Calabar. The Obong of Calabar placed not only Calabar, but also the Efike and Ibibio (in the Peninsula) under the status of a British protectorate via a Treaty on 10 September 1884. The chiefs of Efike and Ibibio were co-signatories to the Treaty. Subsequently, through a series of bilateral treaties and other legal instruments, the territory was ceded by the 


\section{Implications of the Bakassi conflict resolution for Cameroon}

British in 1913, first to Germany, and later placed under the mandate of the League of Nations and the Trusteeship of the United Nations in 1919 at the end of the First World War. Finally, it was ceded by plebiscite to independent Cameroon in 1961.

The critical legal instruments that changed the status of the Peninsula and its inhabitants were the following (Aghemelo and Ibhasebhor 2006; Omoigui 2006):

- The agreement between the United Kingdom and Germany signed in London on 11 March 1913 entitled '(1) the Settlement of the Frontier between Nigeria and the Cameroons, from Yola to the sea, and (2) the Regulation of Navigation on the Cross River'.

- The Anglo-German Protocol signed in Obokun on 12 April 1913, demarcating the Anglo-German boundary between Nigeria and Kamerun ${ }^{5}$ from Yola to the Cross River. Eight maps accompanied this Protocol.

- The exchange of letters between the British and German governments on 6 July 1914.

- The endorsement, in April 1961, by both the United Nations General Assembly and the International Court of Justice, of the results of the plebiscites conducted in Northern and Southern Cameroons in 1959 and on 11 February 1961, respectively.

- The Diplomatic Note, accompanied by a map, dispatched to the government of Cameroon by Nigeria in 1962, accepting the results of the plebiscites.

For the Bakassi Peninsula in particular, the Germans were interested in getting assurance that Britain would not seek to expand eastwards. The British were interested in uninterrupted and secure sea route access to Calabar, a key trading port. Since the Germans already had the option of using the Douala port, they conceded the 'navigable portion' of the offshore border to Britain. In exchange,

5 The appellations 'Kamerun', 'Cameroun' and 'Cameroons' can be used interchangeably to refer to Cameroon depending on whether the perspective is that of the Germans, Francophones or Anglophones, respectively. 


\section{Francis Menjo Baye}

Britain conceded the Bakassi Peninsula proper to Germany. ${ }^{6}$ Note that 'Nigeria' did not yet exist as an independent state in 1913.

In January 1914, 'Nigeria' was created by amalgamation of the various British protectorates spanning the north to the south. At the end of the First World War, all German territories were divided between France and Britain by the Treaty of Versailles. The League of Nations placed them under French or British mandate. The boundaries between British and French mandated Kamerun were defined by the Franco-British Declaration of 10 July 1919. In this agreement, Bakassi and the rest of what became known as 'British Cameroons' were placed under British mandate and administered coterminous with 'Nigeria' but not merged. The old 1913 border was retained. To codify this further, other agreements were signed on 29 December 1929 and 11 January 1930 between Britain and France. These declarations were ratified and incorporated in an Exchange of Notes on 9 January 1931 between the French Ambassador in London and the British Foreign Minister. Again, maps from that period show the Bakassi Peninsula within 'British Cameroons' (Omoigui 2006).

\subsection{The advent of independence}

On 1 January 1960 and on 1 October 1960, the French Cameroun and Nigeria became independent, respectively. Instruments creating the new countries and exchange of notes between France and Cameroun rehashed all its colonial boundaries as defined by previous colonial agreements. A plebiscite was held to 'clarify the wishes of the people living in Northern and Southern Cameroons under British rule'. The population of Northern Cameroons still under British rule had earlier - in 1959 - 'decided to achieve independence by joining the independent Federation of Nigeria'. The population of Southern Cameroons 'decided to achieve independence by joining the independent Republic of Cameroun' on 11 February 1961 (United Nations 1961). There were 21 polling stations on the Bakassi Peninsula itself and about $73 \%$ of the people living

6 In other words, to get Germany's cooperation not to threaten access to Calabar, Bakassi Peninsula was conceded by Britain. 


\section{Implications of the Bakassi conflict resolution for Cameroon}

there voted to 'achieve independence by joining the independent Republic of Cameroun' (Omoigui 2006). ${ }^{7}$

Moreover, by Diplomatic Note No. 570 of 27 March 1962, the government of Tafawa Balewa of Nigeria exchanged diplomatic notes with Cameroon acknowledging the fact that Bakassi was indeed Cameroonian territory (Aghemelo and Ibhasebhor 2006). In July 1966, Lt.-Col. Gowon came to power in Nigeria. As the Balewa government, he too committed his government to respect all prior international agreements made by the Balewa and Ironsi governments.

\subsection{Political developments and the Bakassi question}

In May 1967, in response to the mandate granted to Lt.-Col. Ojukwu by the selfimposed Eastern Consultative Assembly to secede, Lt.-Col. Gowon created 12 new states in Nigeria - including the South-Eastern State headed by an Ibibio officer. The creation of the South-Eastern State from the former Eastern Region rekindled interest in rejoining Nigeria among Efike and Ibibio residents of the Bakassi Peninsula - many of whom had actually voted in 1961 not to pursue integration with Nigeria. In July 1967, the Nigerian Civil War broke out and lasted until January 1970.

In April 1971, there was a summit meeting between General Gowon of Nigeria and Alhaji Ahmadou Ahidjo of Cameroon in Yaoundé. It was at this meeting that Gowon and Ahidjo agreed to define the navigable channel of the AkpaYafe River up to Point 12. During the summit, Ahidjo asked his survey expert to stop arguing and asked Gowon to draw the line where he wanted it, and Gowon turned to his own technical expert for guidance. The expert marked a point on the map and Gowon drew the line towards that point (Omoigui 2006). Unfortunately, the line Gowon drew - on direct advice from the Director of

7 By spelling it as 'Cameroon', rather than 'Cameroun', the UN created an opening for some mischievous 'Southern Cameroonians' to later say they never voted to join 'Cameroun' which is the former French territory. 


\section{Francis Menjo Baye}

Federal Surveys - was not the true navigable channel of the Akpa-Yafe River as established by the colonial masters. ${ }^{8}$

Two months later, in June 1971, the Joint Boundary Commission met in Lagos, led by Chief Coker for Nigeria and Mr Ngo for Cameroon. They extended the already faulty Gowon-Ahidjo 'compromise line' outwards to the sea in what became known as the Coker-Ngo line. A few weeks later, following the signing of the Coker-Ngo line, Gowon discovered what had transpired. In May 1972, the joint boundary commission met, followed in August 1972 by a summit meeting at Garoua, where General Gowon tried repeatedly without success to get Ahidjo to agree to the reversal and renegotiation of the Gowon-Ahidjo/Coker-Ngo line. An oil rig was erected offshore by the Ahidjo government in 1974, and later in June 1975 in a highly reluctant compromise to accommodate the rig, Gowon conceded a tiny part of Nigerian maritime territory to Cameroon.

On 29 July 1975, General Gowon was overthrown in a coup d'état. The new regime decided to question the 1971 and 1975 Gowon-Ahidjo maritime agreements - either without really understanding the issues or by acting mischievously. In no time the country got the impression that Gowon had given away the 'Bakassi Peninsula' to Cameroon to compensate for President Ahidjo's neutrality during the Nigerian Civil War, an unfortunate and totally false notion which persists in many quarters to this day (Omoigui 2006; Olumide 2002). Many commentators still do not realise that the Peninsula had been ceded by a series of actions and inactions beginning as far back as 1913, reconfirmed when Nigeria became independent in 1960, finalised with the 1961 plebiscite and affirmed with the 1964 Organisation of African Unity (OAU) declaration, which stipulated that independent African countries were bound to respect their colonial borders (Omoigui 2006).

8 Not only did it run right into a ridge, but the line also crisscrossed the navigable channels of the Calabar and Cross rivers, which the British had intended (with German agreement) to be completely on the Nigerian side, west of the Akpa-Yafe channel. 


\section{Implications of the Bakassi conflict resolution for Cameroon}

\section{Implications of the ICJ ruling and the Green-tree Agreement}

\subsection{Ruling of the ICJ and difficulties in implementation}

Cameroon tabled its border dispute with Nigeria before the ICJ in 1994 following the occupation of the Bakassi territory by the Nigerian troops on 12 December 1993. Cameroon anchored its claim over the ownership of Bakassi on the AngloGerman Treaty of 11 March 1913 when both territories now called Cameroon and Nigeria were under colonial rule. Nigeria tried unsuccessfully to challenge the legal basis of the 1913 Treaty, arguing that the two colonial masters had no locus standi to cede territories and that the agreement was not ratified by any of the parliaments of the two nations. Nigeria also unsuccessfully maintained that the alleged ceding of the Peninsula by Gowon was not endorsed by the Supreme Military Council, which was the law-making body of the country at the time (Aghemelo and Ibhasebhor 2006).

On 10 October 2002, after eight years of deliberations, the ICJ at The Hague decided that Cameroon had sovereignty over Bakassi, basing its decision on old colonial documents (Lacey and Banerjee 2002). The boundaries in the Lake Chad region were determined by the Thomson-Marchand Declarations of 1929-1930 and the boundary in Bakassi was determined by the AngloGerman Treaty of 11 March 1913. The Court requested Nigeria to quickly and unconditionally withdraw her administration, police and military from the area of Lake Chad under Cameroonian sovereignty and from the Bakassi Peninsula. The ICJ equally requested Cameroon to expeditiously and without condition remove any administration or military or police forces which may be present along the land boundary from Lake Chad to the Bakassi Peninsula on territories which, pursuant to the judgment, fall within the sovereignty of Nigeria.

The Court fixed the land boundaries from Lake Chad in the north to Bakassi in the south. However, the Court did not specify a definite location off the coast of Equatorial Guinea where the maritime boundary between the two countries would terminate (Bekker 2003). The immediate reaction was that Nigeria rejected the ruling, and at one point it seemed possible that the dispute 


\section{Francis Menjo Baye}

would flare into open war, but UN mediation brought the two sides to the table (Friends of the Earth 2003; Sango 2002).

When it became difficult to implement the ICJ ruling, the UN Secretary-General formed the Cameroon-Nigeria Mixed Commission on the request of both leaders. The Mixed Commission first demarcated the land boundaries. ${ }^{9}$ The development of projects to promote joint economic ventures and cross-border cooperation monitored by the Mixed Commission included the construction of border markets and roads linking the two countries. All appeared on track - some villages further north and around Lake Chad were exchanged until the handing-over process reached the oil-rich Bakassi Peninsula. Two withdrawal timetables were not respected; thousands of Nigerians in the Bakassi Peninsula were not sure where they stood in terms of citizenship and many wanted to remain Nigerians since they had more social and economic ties with Nigeria (Borzello 2004). Nigeria's failure to give Cameroon full control of Bakassi on 15 September 2004 was predicated on the argument that their withdrawal would lead to the collapse of law and order.

In addition, Nigeria submitted that the most democratic manner to decide Bakassi's sovereignty would be to hold a referendum since about $90 \%$ of the people on the Peninsula did not want to become Cameroonian (Eboh 2005). Nigeria claimed that sovereignty of Bakassi was not a matter of oil or natural resources on land or in coastal waters, but rather the welfare and well-being of Nigerians on their land (Federal Republic of Nigeria 2002). There were calls on the Nigerian government by some Nigerians to go to war over the matter. This school of thought argued that 'there is no morality in international relations' and that it is against the national interest of Nigeria in terms of security and economic interest to accept the ICJ's verdict in its totality (Etim-Bassey 2002). However, other Nigerians cautioned against war - arguing that women and

9 The Mixed Commission's mandate covered the following areas: (1) The demarcation of the land boundary between the two countries; (2) The withdrawal of civil administration, military and police forces and transfer of authority in relevant areas along the boundary; (3) The eventual demilitarisation of the Bakassi peninsula; (4) The need to protect the rights of the affected populations in both countries; (5) The development of projects to promote joint economic ventures and cross-border cooperation; and (6) The reactivation of the Lake Chad Basin Commission. 


\section{Implications of the Bakassi conflict resolution for Cameroon}

children are the most vulnerable victims of war - and that youths are the greatest losers in all social conflicts, domestic or international, not the men who usually ask for war (Asobie 2003). They further maintained that 'the principle of good faith' in international relations demands that Nigeria should not disavow her word of honour as evidenced by the Diplomatic Note of 1962 (Aghemelo and Ibhasebhor 2006).

There is no doubt that the ICJ has a limited capacity to facilitate enforcement because there is a very weak interplay between passing judgement and binding enforcements. Implementation of rulings of the ICJ is largely dependent on the goodwill of countries in conflict. In situations where the countries involved are outward looking and cherish international credibility, diplomatic pressure can act as a credible tool which can be used to generate incentives for compliance with international obligations.

\subsection{The Green-tree Agreement}

Following intense diplomatic offensives and the good office of the UN SecretaryGeneral, Cameroon was able to secure the Green-tree Agreement with Nigeria on June 12, 2006, brokered by the UN Secretary-General and witnessed by Britain, France, Germany, and the United States. ${ }^{10}$ Under the Agreement, the Nigerian troops were to withdraw within a maximum of ninety days and a transition period of two years was given for the Nigerian administration to be replaced by the Cameroonian administration. Nigerians living in the Peninsula would be able to remain there under a special regime for four years after Cameroon takes full control and could stay on after that if they so wish.

According to the then Nigerian President Olusegun Obasanjo, the Green-tree Agreement was a great achievement in conflict prevention, which practically reflected its cost-effectiveness when compared with the alternative of conflict resolution. He urged that it should represent a model for the resolution of similar conflicts in Africa and the world at large. Moreover, President Obasanjo had played a leading role in conflict resolution among African states. His refusal

10 Experts had noted that it was in the United States' interests to resolve the dispute to provide 'secure operating environment for oil companies' including Exxon-Mobil, which is active in the region (Friends of the Earth 2003). 


\section{Francis Menjo Baye}

to respect the ICJ verdict would have left an unfavourable spot on his record. Meanwhile, his decision to respect the ICJ verdict and withdraw Nigerian military forces from Bakassi met with strong opposition from some radicals, who felt that Nigeria's military might should be used for expansionist ambitions. In the same spirit with President Obasanjo, President Paul Biya underscored the importance of respecting the ICJ ruling, arguing that their personal credibility and that of the UN depended greatly on its implementation and that it will begin a new era of trust, peace and cooperation between Cameroon and Nigeria.

On 14 August 2006, the Nigerian troops, in a solemn ceremony, peacefully withdrew from the Bakassi Peninsula, marking the climax of a long and meandering peace process that spanned a period of 12 years. The effective withdrawal of Nigerian forces from Bakassi is an indication that it is possible for African nations who find themselves in conflict over territorial rights and other issues to resolve the matter amicably - thus avoiding carnage, blood-shed, socioeconomic and political dislocations, which many post-independent African countries have suffered. Other things being equal, the Green-tree Agreement and the various stages that led up to the handing over is a model for the peaceful settlement of disputes in Africa. The entire process was graced by the Treaty of Calabar between Cameroon and Nigeria on 14 August 2008 that marked the complete withdrawal of the Nigerian administration and police as stipulated in the Green-tree Agreement.

\subsection{Socio-economic implications of the Bakassi conflict resolution}

Reflections on the possible socio-economic implications of the Bakassi conflict resolution are anchored on expenditure-reducing and expenditure-switching effects of peaceful settlements, wealth-generating effects of international credibility, cross-border activities enhanced by the new-found confidence and the need for accompanying measures.

\subsubsection{Expenditure-reducing and switching effects}

In an escalating border conflict situation, the countries involved generally spend much more on security and military activities. Such military spending often crowds out social spending on health, education and infrastructure, a practice 


\section{Implications of the Bakassi conflict resolution for Cameroon}

that negatively affects the welfare situation of the citizenry. As hostilities are scaled down through a negotiated settlement, wasteful military spending is scaled down as well, hence the expenditure-reducing effect of peaceful settlement of border conflicts.

At the same time, there are potentials and incentives to switch from military spending to social sector spending, a situation that will enhance the general welfare of the population. In the case of the Bakassi Peninsula dispute settlement between Cameroon and Nigeria, both countries will realise savings in military and associated logistical expenditures. These savings can be more judiciously used to enhance the standards of living of the various populations via infrastructural development that generates income and employment opportunities. The success of these, however, depends on the good faith of the governments in place and the reducing of corruption.

\subsubsection{Wealth-generating effects}

The peaceful settlement of the Bakassi dispute has increased the international credibility of the presidents of Cameroon and Nigeria, as well as that of the economy of both countries. This new-found credibility would act as an incentive to both domestic and foreign investors to invest and create employment opportunities, which will provoke income-generating activities that are badly needed to reverse the dismal socio-economic situation of the bulk of the populations of both countries.

In particular, Cameroon can now valorise her oil deposits and promote modern fishing in the Peninsula, especially at a time when the country is reaping the fallouts of the 2006 completion point of the heavily indebted poor countries (HIPC) initiative. This will be facilitated both by the peace dividend and the design of accompanying incentives to pull in trans-national oil and fishing companies. The effective exploitation of these resources will improve Cameroon's trade balance, fiscal revenue and resources for her poverty eradication programmes. This is consistent with the three major contributions that investment in oil development is expected to bring to the host country - employment opportunities, foreign 


\section{Francis Menjo Baye}

exchange earnings, and technology transfer that enhances local capacities (Oruwari and Owei 2005).

\subsubsection{Cross-border activities}

Due to historical and ethno-linguistic ties between Cameroon and Nigeria, even during hostilities, trans-border trading did not stop (Konings 2005). It is expected that with the peaceful handing over of Bakassi to Cameroon, fruitful socioeconomic activities between the two countries will be revamped. In this regard, it will be in the interest of both countries if more formal trading arrangements are negotiated, so as to curb smuggling, enhance the competitiveness of home industries and increase tax revenues accordingly.

Cross-border activities will be enhanced further if Cameroon and Nigeria push forward their intentions to initiate a number of political and economic confidence-building measures, and to consider the adoption of a treaty of friendship and non-aggression between them. To crown it all, the Bakassi story illustrates the crucial role of multilateral measures, such as the potential for dialogue and conflict resolution offered by recourse to the ICJ. The Mixed Commission also represents a remarkable initiative and can be seen as an excellent model for preventive diplomacy and a precious tool for moving from a culture of confrontation to a culture of peace. ${ }^{11}$

Notwithstanding this apparent success story in conflict settlement, a few months before 14 August 2008 - the date Nigerian administration and police were expected to finally pull out from the Peninsula as per the June 2006 Green-tree Agreement - a succession of armed attacks suggested that social

11 Indeed, both nations exchange delegations on a regular basis, and the Presidents customarily send messages of congratulation to each other on festive occasions. This happened even at the peak of hostilities in the Bakassi area. A noted example is the visit of a Cameroon delegation to Nigeria in 1995 'in order to canvass support for Cameroon's membership in the Commonwealth' (Mbuh 2004: 2). 


\section{Implications of the Bakassi conflict resolution for Cameroon}

movements were actively at work trying to undermine the process. ${ }^{12}$ These attacks were perhaps meant to undermine the entire process of sustaining the peaceful settlement. However, subsequent to the first attack, Nigeria dispatched a high-level government delegation led by the Minister of State for Foreign Affairs to Yaoundé to present the condolence of the government and people of Nigeria following the brutal killing of Cameroonian Officers. In addition, Nigerian authorities stated and re-stated their resolve to respect international commitments on the conflict settlement.

\subsubsection{The need for accompanying measures}

Accompanying measures by Cameroon, Nigeria and the international community, as well as other socio-economic and political developments emanating from the entire border conflict settlement are needed to enhance the peace dividend.

The government of Cameroon needs to carry out important infrastructural developments in the health, education, road, water and telecommunications domains in the Peninsula. This will ease the precarious living conditions of the Bakassi residents and act as incentives for other Cameroonians to accept working there. This will also help to discourage any social movements that may be nurturing the intention to instigate the Bakassi indigenous people to reject the peace dividends that they stand to gain from the implementation of the Green-tree Agreement. Moreover, it cannot be ruled out that the recent in-land and amphibious attacks on Cameroonian civilians and military in the Peninsula were perpetrated by negative social movements and their sponsors in or out of Cameroon.

12 In particular, (1) on 12 November 2007 an attack by unidentified assailants left 21 Cameroonian military personnel dead, (2) on 9 June 2008 another armed group attacked and killed six Cameroonian officials including the Divisional Officer, (3) on 11 July 2008 yet another attack left three officials wounded, and (4) on 24 July 2008 another attack left two Cameroonian marines on patrol dead and four wounded (Forbinake 2008). For the first time, ten of the assailants were killed by Cameroonian forces and eight captured (official government statement over the Cameroon Radio and Television on 24 July 2008). A local private newspaper (Messager 2008) quoted statements issued by one General A. G. Basua and Commandant Ebi Dari claiming responsibility for the recurrent attacks on behalf of the Niger Delta Defence and Security Council. 


\section{Francis Menjo Baye}

It will be encouraging if the international community were to recognise and reward the remarkable level-headedness exercised by the two statesmen, Paul Biya and Olusegun Obasanjo, in the conflict resolution process, and subsequently also by President Yar'Adua of Nigeria. Such a reward, which could take the form of a joint peace award, might act as a catalyst to encourage other countries in conflict to opt for peaceful settlements. In addition, the donor community, acting individually or in coalition, could assist in infrastructural developments in the Bakassi Peninsula. Moreover, as implied by the then President Obasanjo after the signing of the Green-tree Agreement, an alternative to the peaceful resolution of the conflict could have been military confrontations with rippling effects transmitted across the sub-region that would have entailed much more assistance for humanitarian activities from the international community.

Subsequent to the complete withdrawal of Nigerian authorities from the Bakassi Peninsula, oil resources have not been exploited in this area, yet the government of Cameroon and its development partners, especially the European Union through the European Development Fund and the French Development Agency, from 2007 to 2009, spent over CFAF 12 billion to execute some priority projects. The government of Cameroon created a Coordination and Follow-up Committee for the implementation of these Priority Projects in the Bakassi Peninsula on August 27, 2007. Priority projects have been carried out in Idabato, Kombo Itindi, Kombo Abedimo and Bamusso Subdivisions. These projects include the construction of classrooms, government offices, health centres, residences for workers, markets, speed-boats for administrative authorities, water supply, generators for energy supply, social centres, women's empowerment centres and support to farmers' organisations (Kendemeh 2010).

According to the progress report presented on 11 March 2010 by Lekunze Ketuma, chair of the Follow-up Committee, a pressing problem for the administration is how to people the area with Cameroonian nationals and motivate government workers to go and work in Bakassi. Among projects earmarked for 2010 worth CFAF 2,5 billion with a view to reducing this problem are the construction of camps for fishermen (and providing them with fishing gear), the construction of improved facilities for communal fish smoking, the extension of oil palm plantation and the construction of camps for workers, 


\section{Implications of the Bakassi conflict resolution for Cameroon}

and the tarring of the Loum-Kumba-Ekondo-Titi-Mundemba-Isangele-Akwa road (Kendemeh 2010). Other projects include mobile telephone relay antennas, a CRTV (Cameroon Radio and Television) signal relay tower and a broadcast centre. Notwithstanding these efforts, the general impression is that the process has been rather slow.

The first-ever Fish Festival chaired by the Cameroon Minister of Livestock, Fisheries and Animal Industries held in Bamusso Subdivision in April 2010 brought together local and foreign fishermen, traditional rulers, and administrative and municipal authorities (Efande 2010). The occasion is seen as promoting fishing in the Bakassi area and as encouraging peaceful co-existence between natives and foreigners in tandem with the Green-tree Agreement.

\section{Concluding Remarks}

This paper evaluated the implications of the Bakassi conflict settlement between Cameroon and Nigeria for sustainable peace and economic development. Specifically, the paper (1) developed a conceptual framework of international conflict dynamics and resolution; (2) examined the geopolitics of the Bakassi dispute; and (3) discussed the implications of the Bakassi conflict resolution for socio-economic development and international conflict resolution.

The colonial powers subjugated and divided Africa disregarding the relationship between territorial boundaries and the anthropogenic homogeneity and/or characteristics of the various ethnic groupings. International conflicts were depicted as being shaped by: the nature and size of the booty that would accrue from the conflict, the nature of the relationship between the social classes that constitute the main actors in the conflict, and the nature of domestic politics in nation-states that form the bases for the contending parties.

The effective withdrawal of the Nigerian military, police and administration from Bakassi indicates that it is possible for African countries in conflict to resolve matters amicably and avoid carnage, blood-shed, socio-economic and political dislocations, which many post-independent African nations have inflicted on themselves. Other things being equal, the entire process leading to 


\section{Francis Menjo Baye}

the final handing-over day is a model for the peaceful settlement of disputes in Africa. Reflections on the possible socio-economic implications of the Bakassi conflict resolution were anchored by four aspects: expenditure-reducing and expenditure-switching effects of peaceful settlements; wealth-generating effects of international credibility; cross-border activities enhanced by confidence building; and the need for accompanying measures to weaken sympathies for disruptive views propagated by negative social movements.

There is no doubt that neglect of border areas contributes to the problem of border incursions. Cameroonians along the Nigerian border use mostly foreign currency, watch Nigerian television, listen to Nigerian radio and are cut off from contacts with their own country. Cameroon's new border policy should, therefore, continue to provide for the construction of schools, hospitals, roads, agricultural posts, telecommunications network, pipe-borne water, etc. It is perhaps only by carrying out infrastructural developments and effectively occupying border areas that future incursions can be checked and sustainable peace guaranteed. Rewarding the main protagonists could be catalytic in replicating peaceful settlements of similar international disputes.

\section{Sources}

Aghemelo, A.T. and S. Ibhasebhor 2006. Colonialism as a source of boundary dispute and conflict among African states: The World Court judgement on the Bakassi peninsula and its implications for Nigeria. Journal of Social Science, 13 (3), pp. 177-181. Available from: <www.krepublishers.com/.../JSS-13-3-177-181-2006-346-Aghemelo-A-T-Text.pdf>

Asobie, A. 2003. Nigeria, Cameroun and the unending conflict over Bakassi. Available from: $<$ www.nigerdeltacongress.com/narticles/nigeria_cameroun_and_the_unendin.htm>

Bekker, P.H.F. 2003. Land and maritime boundary between Cameroon and Nigeria (Cameroon v. Nigeria: Equatorial Guinea intervening). The American Journal of International Law, 97 (2), pp. 387-398.

Borzello, A. 2004. My home is another country. BBC News, 19 January. Available from: <http:// news.bbc.co.uk/go/pr/fr/-/1/hi/world/africa/3401407.stm>

Eboh, C. 2005. Nigeria-Cameroon fail to set new Bakassi pullout date. Washington Post Online, 15 October. Available from: <http://www.washingtonpost.com/wp-dyn/content/ article/2005/10/15/AR2005101500498.html>

Efande, P. 2010. Bakassi exhibits potentials in fish production. Cameroon Tribune (Yaoundé), 20 April. 


\section{Implications of the Bakassi conflict resolution for Cameroon}

Etim-Bassey, W. 2002. Before the final ruling: On Akinterinwa's 'In the event of a NigeriaCameroon War'. Available from: $<$ http://nigeriaplanet.proboards43.com/index.cgi?board= article\&action $=$ display\&thread $=1126086422>$

Federal Republic of Nigeria 2002. Nigeria's reaction to the judgment of the International Court of Justice at The Hague (Nigeria, Cameroon with Equatorial Guinea intervening. November). Available from: <http://www.nigeriaembassyusa.org/110802_1.shtml>

Forbinake, N. 2008. Bakassi: August 14 so near, yet so far. Cameroon Tribune (Yaoundé), No. 9146/5345, 23 July.

Friends of the Earth 2003. Conflict, corruption and climate change: George Bush's new oil agenda. Available from: <www.oe.co.uk $>$

Gumne, K.N. 2006. Comprehensive road map for the settlement of the Bakassi conflict: A letter from the Chairman of Southern Cameroons Peoples Organisation (SCAPO) to the Secretary General of the United Nations, Kofi Annan. Available from: <www.icicemac. com/nouvelle/index.php3?nid=5614>

Hoffmann, S. 1985. Raymond Aron and the theory of international relations. International Studies Quarterly, 29 (1), pp. 13-27.

Ivorgba, E.E.A. 2005. A training manual on peace and conflict transformation: A property of the African Christian Youths Development Forum. Available from: <acydfoundation. cfsites.org/files/conflict_transformation.pdf>

Kendemeh, E. 2010. Bakassi: Projects worth CFAF 12 billion executed. Cameroon Tribune (Yaoundé), 15 March.

Klare, Michael T. 2004. Blood and oil: The dangers and consequences of America's growing petroleum dependency. New York, Metropolitan Books/Henry Holt.

Konings, P. 2005. The Anglophone Cameroon-Nigeria boundary: Opportunities and conflicts. African Affairs, 104 (415), pp. 275-301.

Lacey, M. and N. Banerjee 2002. (11 October 2002), World Court rules for Cameroon in prolonged oil-land border dispute with Nigeria. New York Times, 11 October. Available from: <http://www.globalpolicy.org/wldcourt/icj/2002/1011bakassi.htm>

Mbuh, J.M. 2004. International law and conflicts: Resolving border and sovereignty disputes in Africa. London, iUniverse, Inc. Available from: <http://www.postmatchmagazine.com/ files/bakassi_notes.pdf>

Messager 2008. News item on statements by military leaders. Messager No. 2658 (Douala), 21 July.

Olumide, I. 2002. Letter from the Attorney General of the Federation to the Ministry of External Affairs. Punch (Nigerian newspaper), October 12.

Omoigui, N. 2006. The Bakassi story. Available from: <http://www.omoigui.com > [Accessed 18 October]. 


\section{Francis Menjo Baye}

Oruwari, Y. and O. Owei 2005. Contesting livelihood systems in Nigeria's Niger Delta region: The relationship between the State, trans-national oil companies and local communities. Paper presented at Conference on Impact of globalisation on the poor in Africa, 1-2 December 2005, Johannesburg. Organised by UNU-WIDER in collaboration with TIPS, AERC and DPRU/UCT.

Price, F. 2005. The Bakassi Peninsula: The border dispute between Nigeria and Cameroon. ICE Case Studies, No. 163, November. Available from: <www.american.edu/ted/ice/nigeriacameroon.htm>

Rourke, J.J. 1997. International Politics on the World Stage. New York, Dushkin/McGraw Hill.

Sango, S. 2002. No to war over oil: for a democratic referendum among the Bakassi people, Committee for a Workers' International, November 12. Available from: <www. worldsocialist-cwi.org/contents.html>

United Nations 1961. UN General Assembly resolution 1608 (XV) of 21 April 1961.

United Nations 2006. Bakassi peninsula: Recourse to the law to prevent conflict. Available from: $<$ http://www.un.org/events/tenstories/story.asp?storyID=900 $>$ [Accessed 18 October].

\section{Abbreviations}

AERC

$\mathrm{BBC}$

CFAF

DPRU/UCT

ICE

SCAPO

TIPS

UNU

WIDER
African Economic Research Consortium

British Broadcasting Corporation

Communauté Financière Africaine Franc

Development Policy Research Unit/University of Cape Town

Inventory of Conflict and Environment

Southern Cameroons Peoples Organisation

Trade and Industrial Policy Strategies

United Nations University

World Institute for Development Economics Research 